\title{
Effects of Dietary Paper Mulberry (Broussonetia papyrifera) on Growth Performance and Muscle Quality of Grass Carp (Ctenopharyngodon idella)
}

\author{
Tao Tang ${ }^{1}$, Jinhai Bai ${ }^{1}$, Zhipeng Ao ${ }^{1}$, Zehong Wei ${ }^{1, *}$, Yi Hu ${ }^{2}$ and Shaojun Liu ${ }^{1}$ \\ 1 State Key Laboratory of Developmental Biology of Freshwater Fish, College of Life Sciences, Hunan Normal \\ University, Changsha 410081, China; tangtao9094@163.com (T.T.); b13807253562@outlook.com (J.B.); \\ 15170482247@139.com (Z.A.); 1sj@hunnu.edu.cn (S.L.) \\ 2 Hunan Engineering Research Center for Utilization of Characteristics of Aquatic Resources, \\ Hunan Agricultural University, Changsha 410128, China; huyi740322@163.com \\ * Correspondence: zehongw@hunnu.edu.cn
}

check for

updates

Citation: Tang, T.; Bai, J.; Ao, Z.; Wei, Z.; Hu, Y.; Liu, S. Effects of Dietary Paper Mulberry (Broussonetia papyrifera) on Growth Performance and Muscle Quality of Grass Carp (Ctenopharyngodon idella). Animals 2021, 11, 1655. https://doi.org/ $10.3390 /$ ani11061655

Academic Editor: Vittorio M. Moretti

Received: 12 April 2021

Accepted: 28 May 2021

Published: 2 June 2021

Publisher's Note: MDPI stays neutral with regard to jurisdictional claims in published maps and institutional affiliations.

Copyright: (c) 2021 by the authors. Licensee MDPI, Basel, Switzerland. This article is an open access article distributed under the terms and conditions of the Creative Commons Attribution (CC BY) license (https:// creativecommons.org/licenses/by/ $4.0 /)$.
Simple Summary: The quality of muscle plays an important role in improving the economic benefit of aquatic products. The paper mulberry (Broussonetia papyrifera, BP) grows wildly in the south of Asia. In this experiment, grass carps (initial weight: $50.0 \pm 0.5 \mathrm{~g}$ ) were fed diets with the addition of $0 \%, 5 \%$, $10 \%, 15 \%$ and $20 \%$ BP in a control diet (crude protein: $31 \%$, crude fat: $3.8 \%$ ) for 8 weeks. In conclusion, adding 5\% BP did not affect the growth of grass carp. However, the supplementation of $10 \% \mathrm{BP}$ could improve muscle quality through improving muscle hardness, reducing fat accumulation and muscle fiber diameter, at the cost of reducing growth performance.

Abstract: The present study investigated the effects of dietary paper mulberry (Broussonetia Papyrifera, $\mathrm{BP})$ on growth performance, muscle quality and muscle growth-related mRNA expressions of grass carp. Fish (initial weight: $50.0 \pm 0.5 \mathrm{~g}$ ) were fed diets supplemented with $0 \%$ (control diet), 5\%, 10\%, $15 \%$ and $20 \%$ BP for 8 weeks. The results showed that increasing levels of paper mulberry linearly and quadratically decreased the special gain rate (SGR) and increased the feed conversion rate (FCR) of grass carp $(p<0.05)$. Significantly positive quadratic trends were found between paper mulberry levels and muscle crude fat or crude protein of grass carp $(p<0.05)$. In comparison to the control diet, the 10\%BP and 15\%BP groups had significantly decreased muscle crude fat and increased crude protein $(p<0.05)$. The levels of paper mulberry resulted in a linear and quadratic increase in water loss of grass carp muscle $(p<0.05)$, and all groups with paper mulberry supplementation were significantly higher than the control group $(p<0.05)$. Significant positive linear and quadratic trends were found between the paper mulberry levels and muscle fiber diameter or density of grass carp $(p<0.05)$. In comparison to the control diet, the significant differences were found in the $15 \% \mathrm{BP}$ and 20\%BP groups $(p<0.05)$. The muscle adhesiveness and hardness linearly and quadratically increased with the increasing levels of paper mulberry $(p<0.05)$, and both of which increased significantly when the level of paper mulberry reached $10 \%(p<0.05)$. In addition, the increase in paper mulberry linearly and quadratically improved the expressions of myoblast determination protein (MyoD), myogenin (MyoG), paired box protein 7 (Pax7) and myostatin 1 (MSTN1) $(p<0.05)$. When the supplementation of paper mulberry reached $15 \%$, the expressions of all these mRNAs were significantly higher than those of the control group $(p<0.05)$. In summary, adding $5 \%$ paper mulberry did not affect the growth of grass carp. However, the supplementation of $10 \%$ paper mulberry could improve muscle quality through improving muscle hardness, reducing fat accumulation and muscle fiber diameter, at the cost of reducing growth performance.

Keywords: paper mulberry; grass carp; growth; flesh quality; myogenic regulatory factors 


\section{Introduction}

Paper mulberry (Broussonetia papyrifera) belongs to the genus Broussonetia of the mulberry family, which grows widely in the east and south of Asia, such as China and India [1]. Paper mulberry has a long history of utilization in papermaking and medicine industries [2]. Moreover, it has been widely used in feeding sheep, cows, pigs and so on. The leaves of paper mulberry contain $21.6 \%$ of crude protein and $4.3 \%$ of ether extract, both of which are higher than that of other forages [3].

It was reported that adding the appropriate content of paper mulberry in diets improved the growth performance of sheep [4], beef cattle [5] and growing rabbits [3]. However, the anti-nutrition factor tannin limited the addition of paper mulberry in livestock. Previous studies proved that tannin acid formed complexes with carbohydrates and proteins, resulting in a decrease in feed utilization and growth performance of animals [6,7]. Yang et al. [8] found that adding more than $10 \%$ of paper mulberry damaged the apparent digestibility of proteins and dry matter of pigs. Moreover, the high content of fiber affected the monogastric animals' utilization of paper mulberry in comparison to the addition of paper mulberry in ruminants, which in sows and rabbits was lower $[9,10]$.

There were other researchers who showed that paper mulberry improved the meat quality of livestock [11,12]. Hua et al. [11] found that dietary paper mulberry supplementation increased muscle $\mathrm{pH}$, the meat color and water-holding capacity (WHC) of goat. Muscle $\mathrm{pH}$ has a great impact on tenderness and WHC of muscle [13]. WHC reflects the ability of muscle to prevent water from leaking out, so it is an important parameter for evaluating meat quality. The decrease in WHC not only increases the drip loss but also damages the texture of raw meat [14,15]. Xiong et al. [16] found that adding paper mulberry effectively reduced the drip loss (the amount of fluid loss from the muscle, and it is negative related to the WHC) of broiler. In addition, Yang et al. [8] found that adding $10 \%$ paper mulberry increased the contents of fat and sodium glutamate in pig muscle. Both fat and sodium glutamate are helpful in improving the flavor of meat [17]. However, in comparison to livestock, studies on the effects of dietary paper mulberry on aquatic animals are relatively scarce. Chen et al. [18] found that adding a $0.4 \%$ mixture of fermented mugwort and paper mulberry leaves improved the immunity of carp (Cyprinus carpio).

Different from mammals, fish have a long-lasting ability to recruit new skeletal muscle fibers [19]. A previous study proved that there was a negative correlation between the fiber diameter and hardness in the muscle of pigs [20]. Therefore, the mRNAs expression of the factors involved in regulating muscle fiber growth of fish has great potential to optimize muscle quality. In fish, myogenic regulatory factors (MRFs) control the specification and differentiation of myogenic cells [21]. Myostatin 1 (MSTN1) and insulin-like growth factor 2 (IGF2) are the negative and positive regulators of muscle growth, respectively [22]. Paired box protein 7 (Pax7) can regulate the myogenic progenitor cell differentiation [23]. Previous studies investigated the influence of plant protein on muscle growth of fish. Alami-Durante et al. [24] found that plant protein increased the myoblast determination protein (MyoD) expression in rainbow trout, and Li et al. [25] found that faba bean meal improved the expression of MRFs in grass carp (Ctenopharyngodon idellus). However, research related to the effects of paper mulberry on muscle growth of fish is rare.

As a typical herbivorous fish, grass carp has a higher tolerance of plant sources compared to carnivorous and omnivorous fish. In addition, as one of the most productive freshwater fish in China, grass carp have huge yields and demands. The global production of grass carp in 2019 was more than 50 million tons [26]. With the improvement of living standards, consumers' demands for high-quality aquatic products are increasing. Therefore, it has important economic significance to develop a plant raw material that can improve the muscle quality and even the growth performance of grass carp. The present study was conducted to investigate the influence of paper mulberry on the growth performance and muscle quality of grass carp. 


\section{Materials and Methods}

This trial was performed in accordance with the Guide for the Care and Use of Laboratory Animals, and was approved by Hunan Normal University Institutional Animal Care and Use Committee (Changsha, China) under permit No. 20200012.

\subsection{Experimental Diets}

In the experiment diet, soybean meal (crude protein: $44 \%$; crude lipid: $1.9 \%$; energy: $14.26 \mathrm{MJ} / \mathrm{kg}$ ) and fish meal (crude protein: $67 \%$; crude lipid: $8.4 \%$; energy: $13.47 \mathrm{MJ} / \mathrm{kg}$ ) were used as the main protein sources, and soybean oil (crude lipid: $98 \%$; energy: $36.6 \mathrm{MJ} / \mathrm{kg}$ ) was used as the main lipid source. Five experiment diets were formulated by adding $0 \%, 5 \%$, $10 \%, 15 \%$ and $20 \%$ paper mulberry (Broussonetia papyrifera, BP) into the commercial diet (crude protein: $31 \%$, crude fat: $3.8 \%$ ). The paper mulberry was obtained from Zhuozhou station of China Agriculture University (Hebei, China). The formulation of the diet is shown in Table 1. All ingredients were ground to pass a 40 mesh screen, mixed gradually and blended with soybean oil and water. Pellets with a diameter of $2 \mathrm{~mm}$ were produced by a laboratory pellet machine. After drying the pellets at $60{ }^{\circ} \mathrm{C}$ for $5 \mathrm{~h}$, all diets were stored at $-20^{\circ} \mathrm{C}$ in plastic-lined bags until use.

Table 1. Formulation and proximate composition of the experimental diets (dry weight, \%).

\begin{tabular}{|c|c|c|c|c|c|}
\hline Ingredient & Control Diet & $5 \% \mathrm{BP}$ & $10 \% \mathrm{BP}$ & $15 \% \mathrm{BP}$ & $20 \% B P$ \\
\hline Fish meal & 2 & 2 & 2 & 2 & 2 \\
\hline Soybean meal & 20 & 20 & 20 & 20 & 20 \\
\hline Rapeseed meal & 30 & 30 & 30 & 30 & 30 \\
\hline DDGS & 6 & 6 & 6 & 6 & 6 \\
\hline $\mathrm{BP}^{1}$ & 0 & 5 & 10 & 15 & 20 \\
\hline Corn gluten meal & 6 & 6 & 6 & 6 & 6 \\
\hline Wheat flour & 31 & 25.3 & 19.5 & 13.7 & 8 \\
\hline Microcrystalline & 0.26 & 1.25 & 2.34 & 3.44 & 4.43 \\
\hline Soybean Oil & 2 & 1.71 & 1.42 & 1.12 & 0.83 \\
\hline Choline chloride & 0.2 & 0.2 & 0.2 & 0.2 & 0.2 \\
\hline Calcium dihydrogen & 1.5 & 1.5 & 1.5 & 1.5 & 1.5 \\
\hline Premix ${ }^{2}$ & 1 & 1 & 1 & 1 & 1 \\
\hline Antioxidants & 0.01 & 0.01 & 0.01 & 0.01 & 0.01 \\
\hline Ethoxyquin & 0.03 & 0.03 & 0.03 & 0.03 & 0.03 \\
\hline \multicolumn{6}{|c|}{ Proximate analysis (\%) } \\
\hline Moisture & 90.12 & 89.88 & 89.74 & 90.21 & 89.95 \\
\hline Crude protein & 31.04 & 30.78 & 30.89 & 31.21 & 31.15 \\
\hline Crude lipid & 3.88 & 3.98 & 3.92 & 3.75 & 3.77 \\
\hline Crude ash & 8.67 & 8.88 & 8.82 & 8.56 & 8.75 \\
\hline Carbohydrate & 35.46 & 35.05 & 34.86 & 34.36 & 33.95 \\
\hline Energy (MJ/kg) & 14.96 & 14.79 & 14.83 & 14.75 & 14.68 \\
\hline
\end{tabular}

BP = Paper mulberry (Broussonetia papyrifera). Paper mulberry was obtained from Zhuozhou station of China Agriculture University (Hebei, China). ${ }^{2}$ Provided by MGOTer Bio-Tech Co., Ltd. (Qingdao, Shandong, China), mineral premix composition (per $\mathrm{kg}$ ) as follows: $\mathrm{KCl}, 200 \mathrm{mg}$; $\mathrm{KI}(1 \%), 60 \mathrm{mg}$; $\mathrm{CoCl}_{2} \cdot 6 \mathrm{H}_{2} \mathrm{O}(1 \%), 50 \mathrm{mg}$; $\mathrm{CuSO}_{4} \cdot 5 \mathrm{H}_{2} \mathrm{O}, 30 \mathrm{mg} ; \mathrm{FeSO}_{4} \cdot \mathrm{H}_{2} \mathrm{O}, 400 \mathrm{mg} ; \mathrm{ZnSO}_{4} \cdot \mathrm{H}_{2} \mathrm{O}, 400 \mathrm{mg} ; \mathrm{MnSO}_{4} \cdot \mathrm{H}_{2} \mathrm{O}, 150 \mathrm{mg} ; \mathrm{Na}_{2} \mathrm{SeO}_{3} \cdot 5 \mathrm{H}_{2} \mathrm{O}(1 \%)$ $65 \mathrm{mg} ; \mathrm{MgSO}_{4} \cdot \mathrm{H}_{2} \mathrm{O}, 2000 \mathrm{mg}$; zeolite power, $3645.85 \mathrm{mg}$; VB1, $12 \mathrm{mg}$; riboflavin, $12 \mathrm{mg}$; VB6, $8 \mathrm{mg}$; VB12, $0.05 \mathrm{mg}$; $\mathrm{VK} 3,8 \mathrm{mg}$; inositol, $100 \mathrm{mg}$; pantothenic acid, $40 \mathrm{mg}$; niacin acid, $50 \mathrm{mg}$; folic acid, $5 \mathrm{mg}$; biotin, $0.8 \mathrm{mg}$; VA, $25 \mathrm{mg}$; VCP1, $5 \mathrm{mg}$; VE, $50 \mathrm{mg}$; VC, $100 \mathrm{mg}$; ethoxyquin, $150 \mathrm{mg}$; wheat meal, $2434.15 \mathrm{mg}$.

\subsection{Feeding Management}

The experiment was carried out in the Chetianjiang Reservoir in Hunan (Xinghua, Hunan, China). The grass carps were brought from Xiangyin country (Yueyang, Hunan), and 600 grass carps were randomly divided into 15 floating cages $(2.0 \times 1.5 \times 1.5 \mathrm{~m})$ after acclimating for 1 week. There were three replicates for each dietary treatment, and each replicate contained 40 grass carps. Grass carps were fed at the rate of $3-4 \%$ of body weight 3 times per day at 8:00, 12:30 and 16:00 for 8 weeks. The feeding rate was adjusted on a weekly basis to feed the fish to apparent satiation. Water quality indicator data were as 
follows: water temperature was $26.0 \pm 3.3^{\circ} \mathrm{C}$, $\mathrm{pH}$ was $7.3 \pm 0.5$ and dissolved oxygen was $7.0 \pm 0.5 \mathrm{mg} / \mathrm{L}$.

\subsection{Sample Collection}

At the end of the experiment, all fish were euthanized with MS222 (tricaine methane sulfonate, Sigma, St. Louis, MO, USA) at a concentration of $100 \mathrm{ppm}$ after fasting for $24 \mathrm{~h}$. All grass carps were counted and weighted for calculation of growth performance as follows:

Special gain rate $(\mathrm{SGR})=(\operatorname{Ln}($ final body weight $(\mathrm{g}))-\operatorname{Ln}($ initial body weight $(\mathrm{g})) /$ feeding days $\times 100$

Feed conversion rate $(\mathrm{FCR})=$ feed intake $(\mathrm{g}) /$ wet weight gain $(\mathrm{g})$

Survival rate $(\mathrm{SR}, \%)=100 \times($ final number of fish/initial number of fish)

A muscle of $1 \mathrm{~cm} \times 0.5 \mathrm{~cm} \times 0.5 \mathrm{~cm}$ from the right side of three carps per replicate was immersed in $4 \%$ paraformaldehyde for morphometric analysis, and the muscle on the other side $(1 \mathrm{~cm} \times 1 \mathrm{~cm} \times 0.5 \mathrm{~cm})$ was collected for texture analysis. A sample of approximately $9 \mathrm{~g}$ of fresh muscle from three carps ( $3 \mathrm{~g}$ per carp) per replicate was dissected, collected and mixed as one sample ( $n=3$ per dietary treatment) in a $10 \mathrm{~mL}$ microfuge tube, then stored at $-20{ }^{\circ} \mathrm{C}$ for muscle nutritional component and quality analysis. A sample of approximately $3 \mathrm{~g}$ of fresh muscle from three carps (1 $\mathrm{g}$ per carp) per replicate was mixed as one sample ( $n=3$ per dietary treatment) in a $5 \mathrm{~mL}$ microfuge tube and stored at $-80^{\circ} \mathrm{C}$ for the determination of enzymatic activities and quantitative PCR.

\subsection{Muscle Nutritional Component Analysis}

The nutritional component analysis of muscle was conducted by standard methods (AOAC, 2005). Moisture was determined by oven drying to a constant weight at $105^{\circ} \mathrm{C}$ in DHG-9240A (Keelrein Instrument Co., Ltd., Shanghai, China). Protein was determined by measuring nitrogen $(\mathrm{N} \times 6.25)$ using the Kjeldahl method in FOSS Kjeltec 2300 (Foss Analytical Instruments Co., Ltd., Hillerød, Denmark). Lipid was determined by ether extraction using FOSS Soxtec 2050 (Foss Analytical Instruments Co., Ltd., Hillerød, Denmark).

\subsection{Muscle Quality Analysis}

The water-holding capacity (WHC) was conducted by the gravimetric method [27]. About $1 \mathrm{~g}$ of skinned muscle was weighed (S) and wrapped in the filter paper (V1), then put in a centrifuge tube and centrifuged at $4000 \times g$ for $10 \mathrm{~min}$ at room temperature. The wet filter paper (V2) was weighed and dried in an oven $\left(75^{\circ} \mathrm{C}\right)$ to constant weight $(\mathrm{V} 3)$. The following formula was used to calculate the indicators: drip loss $=100 \times(\mathrm{V} 2-\mathrm{V} 3) \times \mathrm{S}^{-1}$; lipid loss $=100 \times(\mathrm{V} 3-\mathrm{V} 1) \times \mathrm{S}^{-1}$.

Muscle $\mathrm{pH}$ value was performed by a $\mathrm{pH}$ meter (testo-205, testo AG, Germany) at room temperature according to the methods described by a previous study [28].

The thiobarbituric reactive substances (TBARs) content was determined by the method of Wang et al. [29] with minor modifications. Muscle samples were homogenized in $20 \mathrm{~mL}$ of trichloroacetic acid solution (ratio of 1:5 (W/V)). After centrifugation at $3500 \times g$ and $4{ }^{\circ} \mathrm{C}$ for $15 \mathrm{~min}$, the resulting supernatant was filtrated. Then, $5 \mathrm{~mL}$ of filtrate was mixed with $5 \mathrm{~mL}$ of 2-thiobarbituric acid (TBA) solution. At the same time, $5 \mathrm{~mL}$ of trichloroacetic acid solution and $5 \mathrm{~mL}$ of TBA solution were mixed as the blank. Both the sample solution and the blank were boiled in a water bath for $15 \mathrm{~min}$. After being cooled with running water, the absorbance of the sample solution (As) and the blank $(\mathrm{Ab})$ was measured at $530 \mathrm{~nm}$. The TBA value (mg of malonaldehyde (MDA) per $100 \mathrm{~g}$ of tissue) was obtained by: $\mathrm{TBA}=50 \times(\mathrm{As}-\mathrm{Ab}) / 200$.

The total volatile base nitrogen (TVB-N) content was detected in FOSS Kjeltec 2300 (Foss Analytical Instruments Co., Ltd., Hillerød, Denmark) according to the GB/T 5009.2282016. In brief, the standard titration solution of HCL $(0.01 \mathrm{~mol} / \mathrm{L})$ was used for titration. The distillation time was set to $180 \mathrm{~s}$, and the titration end point was set as $\mathrm{pH}=4.65$. At first, 
the reagent blank was measured with distilled water, adding $1 \mathrm{~g}$ of $\mathrm{MgO}$. Then, the homogeneous solutions were composed of $10 \mathrm{~g}$ of fish muscle and $75 \mathrm{~mL}$ of distilled water with $1 \mathrm{~g}$ of $\mathrm{MgO}$ as the sample for detection. The determination was according to the conditions set and the requirements of the instrument operation manual. The TVB - $\mathrm{N}$ content $(\mathrm{mg} / 100 \mathrm{~g})$ was calculated as the following formula: TVB $-N=\left(\left(V_{1}-V_{2}\right) \times C \times 14 / m\right) \times 100$.

$\mathrm{V}_{1}$ : volume of $\mathrm{HCl}$ consumed by test solution $(\mathrm{mL}) ; \mathrm{V}_{2}$ : volume of $\mathrm{HCl}$ consumed by reagent blank $(\mathrm{mL})$; $\mathrm{C}$ : concentration of $\mathrm{HCl}(\mathrm{mol} / \mathrm{L})$; $\mathrm{m}$ : sample quality $(\mathrm{g})$.

\subsection{Muscle Texture Measurement}

Muscle texture was evaluated using a TMS-PRO TPA device (Food Technology Corporation, Sterling, VA, USA) equipped with a flat-bottomed cylindrical probe (diameter: $8 \mathrm{~cm}$ ) and a load cell of $250 \mathrm{~N}$. The assay was performed according to the method described by Zhang [30]. All texture profile analysis (TPA) measurements were performed using $1 \mathrm{~cm} \times 1 \mathrm{~cm} \times 0.5 \mathrm{~cm}$ pieces from the dorsal white muscle of each fish. A test of double compression of the samples to $60 \%$ of their height was made. The speed of the roller movement during the test was $1 \mathrm{~mm} / \mathrm{s}$, the gap between pressures was $2 \mathrm{~s}$. The TPA technique was intended to determine texture characteristics: hardness, adhesiveness, cohesiveness, springiness, gumminess and chewiness.

\subsection{Muscle Enzymes Activity Measurement}

About $1 \mathrm{~g}$ of muscle sample was homogenized in $9 \mathrm{~mL}$ of $0.9 \%$ ice-cold sodium chloride buffer and centrifuged at $3000 \times g$ at $4{ }^{\circ} \mathrm{C}$ for $10 \mathrm{~min}$. The supernatant was collected for the contents of lactate, hydroxyproline (HYP), troponin T (TnT) and muscle glycogen analysis at the appropriate dilution. All of it was measured with a commercial kit provided by NanJing Jiancheng Bioengineering Institute.

\subsection{Histological Analysis}

For histological analysis, samples of muscle were fixed immediately in $10 \%$ buffered formalin, subsequently dehydrated with a series of ethanol, infiltrated in xylene and embedded in paraffin wax, as per standard histological protocols. A section of approximately $5 \mu \mathrm{m}$ thickness was stained with hematoxylin and eosin (HE) and digitally photographed under a light microscope (BX40F4, Olympus, Tokyo, Japan).

For the analysis of fiber diameter, the muscle fiber was assumed to be cylindrical, and the diameter was calculated as $\mathrm{s}=\pi \mathrm{r}^{2}$ (where $\mathrm{s}$ is the muscle fire area and $\mathrm{r}$ is the muscle fire radius), according to the method described by [31]. A size limit for identifying fibers was set at fiber diameter $\geq 10 \mu \mathrm{m}$, since the optical resolution below this limit did not allow for sufficient identification and accuracy in the analyses. Muscle fiber density $=$ number of muscle fibers/area selected.

\subsection{Real-Time Quantitative PCR Analysis}

Total RNA was extracted using TRIzol reagent (Invitrogen, USA). The purity of total RNA was measured using a Nanodrop ND-2000 spectrophotometer (Thermo Fisher Scientific, Waltham, MA, USA) for the determination of $\mathrm{OD}_{260}, \mathrm{OD}_{280}$ and $\mathrm{OD}_{230}(\mathrm{OD} 260 / 280 \geq 1.8$ and OD260/230 $\geq 1.5)$. Subsequently, the total RNA was reversely transcribed into cDNA with Super-Script III RNase H-reverse transcriptase (Invitrogen, Carlsbad, CA, USA) according to the manufacturer's instructions. The real-time PCR (q-PCR) was carried out in Bio-Rad CFX96 system (Redmond, WA, USA) with SYBR Premix Ex Taq II (TaKaRa, Dalian, China). A total volume of $25 \mu \mathrm{L}$ of the PCR reaction was composed of SYBR Premix Ex TaqII $(2 \times) 12.5 \mu \mathrm{L}$, forward primer $1 \mu \mathrm{L}(10 \mu \mathrm{M})$, reverse primer $1 \mu \mathrm{L}(10 \mu \mathrm{M})$, cDNA $2 \mu \mathrm{L}$ $(25 \mathrm{ng} / \mu \mathrm{L})$ and sterile double-distilled water $8.5 \mu \mathrm{L}$. The amplification protocol was as follows: pre-denaturation at $95^{\circ} \mathrm{C}$ for $30 \mathrm{~s}$, followed by $95^{\circ} \mathrm{C}$ for $3 \mathrm{~s}$ and $60^{\circ} \mathrm{C}$ for $25 \mathrm{~s}$ (40 cycles). The primers are listed in Table 2, and $\beta$-actin was selected as the internal control. The relative expression ratio $(\mathrm{R})$ of mRNA was calculated using the following equation $\mathrm{R}=2^{-\Delta \Delta \mathrm{Ct}}[32,33]$. 
Table 2. Real-time PCR primer sequences.

\begin{tabular}{|c|c|c|}
\hline Gene & Primer & Accession NO. \\
\hline MyoD & $\begin{array}{l}\text { F 5'-CCCTTGCTTCAACACCAACG-3' } \\
\text { R 5'-TCTCСТCTCССТCATGGTGG-3' }\end{array}$ & GU218462 \\
\hline MyoG & $\begin{array}{l}\text { F 5'-TGAGGGAGAGGAGACGACT-3' } \\
\text { R 5'-GCTCCAGAACAGGGTAGTAGT-3' }\end{array}$ & JQ793897 \\
\hline Mrf4 & $\begin{array}{c}\text { F: 5'-TCATTCAACTTGTGCCCTCC-3' } \\
\text { R: 5'-GCCCACTTTGCGATACCC-3'3 }\end{array}$ & KT899334 \\
\hline Myf5 & $\begin{array}{l}\text { F: } 5^{\prime} \text {-GGAGAGCCGCCACTATGA-3' } \\
\text { R: } 5^{\prime} \text {-GCAGTCAACCATGCTTTCAG-3' }\end{array}$ & AB012883 \\
\hline Pax7 & $\begin{array}{c}\text { F: } 5^{\prime} \text {-CAAGAAACTGGCTCAATCCG-3' } \\
\text { R: } 5^{\prime} \text {-TCGCAATCGTCCTCATCG-3' }\end{array}$ & KJ195463.1 \\
\hline IGF2 & $\begin{array}{l}\text { F: 5'-GCTTCCACAAACCGCCTACC-3' } \\
\text { R: 5'-AAAGAGTCTCCGCCGTTGCT-3' }\end{array}$ & EF062860 \\
\hline MSTN1 & $\begin{array}{l}\text { F: 5'-GCAGGAGTCACGTCT TGGCA-3' } \\
\text { R: 5'-GAGTCCCTCCGGATTCGCTT-3' }\end{array}$ & KM874826 \\
\hline$\beta$ actin & $\begin{array}{l}\text { F: 5'-GGCTGTGCTGTCCCTGTA-3' } \\
\text { R: 5'-GGGCATAACCCTCGTAGAT-3' }\end{array}$ & M25013 \\
\hline
\end{tabular}

$\overline{\mathrm{MyoD}}=$ myoblast determination protein, $\mathrm{MyoG}=$ myogenin, Mrf4 = myogenic regulatory factor 4, Myf5 $=$ myogenic factor 5, Pax7 = paired box protein 7, IGF2 = insulin-like growth factor 2, MSTN1 = myostatin .

\subsection{Statistical Analysis}

The statistical analyses were performed using software (SPSS 18.0). All data were presented as mean \pm S.E. and analyzed by one-way ANOVA followed by Tukey's test to inspect all differences among the dietary treatments. In addition, to determine if the effect was linear and/or quadratic, a follow-up trend analysis using orthogonal polynomial contrasts was performed [34]. A significant difference was considered at $p<0.05$.

\section{Results}

\subsection{Effect of Paper Mulberry on Growth Performance of Grass Carp}

The effects of dietary paper mulberry on the growth performance of grass carp are shown in Table 3. Accordingly, BP had no significant influence on the SR of grass carp $(p>0.05)$. Increasing levels of paper mulberry linearly and quadratically decreased the SGR of grass carp $(p<0.05)$. In comparison to the control diet, when the supplementation of paper mulberry reached $10 \%$, the SGR of grass carp decreased significantly $(p<0.05)$. Moreover, increasing levels of paper mulberry linearly and quadratically increased the FCR of grass carp $(p<0.05)$, and the FCR of the $15 \% \mathrm{BP}$ and $20 \% \mathrm{BP}$ groups were significantly higher than that of the control diet $(p<0.05)$.

Table 3. Growth performance of grass carp fed a diet with paper mulberry (BP) for 8 weeks.

\begin{tabular}{cccccc}
\hline & $\begin{array}{c}\text { Initial } \\
\text { Weight }(\mathbf{g})\end{array}$ & $\begin{array}{c}\text { Final Weight } \\
\mathbf{( g )}\end{array}$ & SGR (\%) & FCR & SR (\%) \\
\hline Control diet & $49.93 \pm 0.07$ & $141.42 \pm 3.31^{\mathrm{b}}$ & $1.71 \pm 0.04^{\mathrm{b}}$ & $1.46 \pm 0.04^{\mathrm{a}}$ & $95.00 \pm 0.00$ \\
$5 \% \mathrm{BP}$ & $50.20 \pm 0.04$ & $131.04 \pm 1.97^{\mathrm{ab}}$ & $1.57 \pm 0.02^{\mathrm{ab}}$ & $1.67 \pm 0.03^{\mathrm{ab}}$ & $90.00 \pm 3.82$ \\
$10 \% \mathrm{BP}$ & $50.00 \pm 0.11$ & $124.38 \pm 5.47^{\mathrm{a}}$ & $1.49 \pm 0.07^{\mathrm{a}}$ & $1.64 \pm 0.08^{\mathrm{ab}}$ & $92.50 \pm 3.82$ \\
$15 \% \mathrm{BP}$ & $50.03 \pm 0.08$ & $116.57 \pm 3.77^{\mathrm{a}}$ & $1.39 \pm 0.05^{\mathrm{a}}$ & $2.06 \pm 0.04^{\mathrm{c}}$ & $96.67 \pm 2.20$ \\
$20 \% \mathrm{BP}$ & $49.98 \pm 0.04$ & $121.25 \pm 1.08^{\mathrm{a}}$ & $1.45 \pm 0.02^{\mathrm{a}}$ & $1.84 \pm 0.01^{\mathrm{bc}}$ & $95.83 \pm 0.83$ \\
$\begin{array}{c}\text { p value } \\
\text { ANOVA }\end{array}$ & 0.156 & 0.004 & 0.004 & 0.000 & 0.421 \\
$\begin{array}{c}\text { Linear trend } \\
\text { Quadratic } \\
\text { trend }\end{array}$ & 0.783 & 0.001 & 0.001 & 0.001 & 0.341 \\
\hline
\end{tabular}

$\overline{\mathrm{SGR}}=$ special growth rate, $\mathrm{FCR}=$ feed conversion rate, $\mathrm{SR}=$ survival rate. Data are expressed as mean $\pm \mathrm{S} . \mathrm{E}$. Values with different superscripts are significantly different $(p<0.05, n=3)$. 


\subsection{Effect of Paper Mulberry on Muscle Nutritional Component of Grass Carp}

As shown in Table 4, there were no significant differences in muscle moisture among all groups $(p>0.05)$. Positive quadratic trends were found between the paper mulberry levels and muscle crude fat or protein of grass carp $(p<0.05)$. In comparison to the control diet, the 10\%BP and 15\% BP groups had significantly decreased muscle crude fat and increased crude protein $(p<0.05)$.

Table 4. Muscle nutritional component of grass carp fed a diet with paper mulberry (BP) for 8 weeks.

\begin{tabular}{|c|c|c|c|}
\hline & Moisture (\%) & $\begin{array}{c}\text { Crude Fat } \\
\text { (\% Dry Matter) }\end{array}$ & $\begin{array}{l}\text { Crude Protein } \\
\text { (\% Dry Matter) }\end{array}$ \\
\hline Control diet & $78.42 \pm 0.31$ & $15.87 \pm 0.44^{b}$ & $81.80 \pm 0.16^{\mathrm{a}}$ \\
\hline $5 \% \mathrm{BP}$ & $78.15 \pm 0.12$ & $14.74 \pm 0.19 \mathrm{ab}$ & $82.67 \pm 0.52^{a b}$ \\
\hline $10 \% \mathrm{BP}$ & $77.81 \pm 0.36$ & $14.38 \pm 0.22^{a}$ & $84.31 \pm 0.26^{c}$ \\
\hline $15 \% \mathrm{BP}$ & $78.47 \pm 0.22$ & $14.08 \pm 0.32^{\mathrm{a}}$ & $83.34 \pm 0.33^{b c}$ \\
\hline $\begin{array}{l}20 \% \text { BP } \\
p \text { value }\end{array}$ & $77.92 \pm 0.48$ & $14.92 \pm 0.27^{\mathrm{ab}}$ & $82.96 \pm 0.20^{a b c}$ \\
\hline ANOVA & 0.538 & 0.016 & 0.003 \\
\hline Linear trend & 0.510 & 0.064 & 0.093 \\
\hline Quadratic trend & 0.763 & 0.002 & 0.003 \\
\hline
\end{tabular}

Data are expressed as mean \pm S. E. Values with different superscripts $\left({ }^{a}, b, c\right)$ are significantly different $(p<0.05$, $n=3)$.

\subsection{Effect of Paper Mulberry on Muscle Texture of Grass Carp}

As is described in Figure 1, no significant influence was observed on muscle gumminess and chewiness of grass carp $(p>0.05)$. The levels of paper mulberry linearly and quadratically influenced muscle adhesiveness, hardness and cohesiveness $(p<0.05)$. In comparison to the control diet, when the supplementation of paper mulberry reached $10 \%$, the adhesiveness and hardness of grass carp increased significantly $(p<0.05)$. The cohesiveness in the $10 \% \mathrm{BP}$ group was significantly lower than that of the control diet $(p<0.05)$.

\subsection{Effect of Paper Mulberry on Muscle Water-Holding Capacity and pH of Grass Carp}

The influence of paper mulberry on the WHC and $\mathrm{pH}$ of grass carp muscle are shown in Table 5. There were no significant differences in lipid loss and $\mathrm{pH}$ of grass carp muscle among all the groups $(p>0.05)$. Positive linear and quadratic trends were found between paper mulberry levels and muscle water loss of grass carp $(p<0.05)$. In comparison to the control diet, all the groups with the supplementation of paper mulberry had significantly increased muscle water loss of grass carp $(p<0.05)$.

\subsection{Effect of Paper Mulberry on Muscle TVB-N and TBARs of Grass Carp}

The influence of paper mulberry on the content of TVB-N and TBARs in grass carp muscle are listed in Table 6. Paper mulberry had no significant influence on TVB-N content in grass carp muscle $(p>0.05)$. The levels of paper mulberry significantly affected the muscle TBARs of grass carp $(p<0.05)$. However, no significant linear or quadratic trend was found between TBARs and paper mulberry contents. There was a significant difference between the $20 \% \mathrm{BP}$ group and the control diet $(p<0.05)$. 

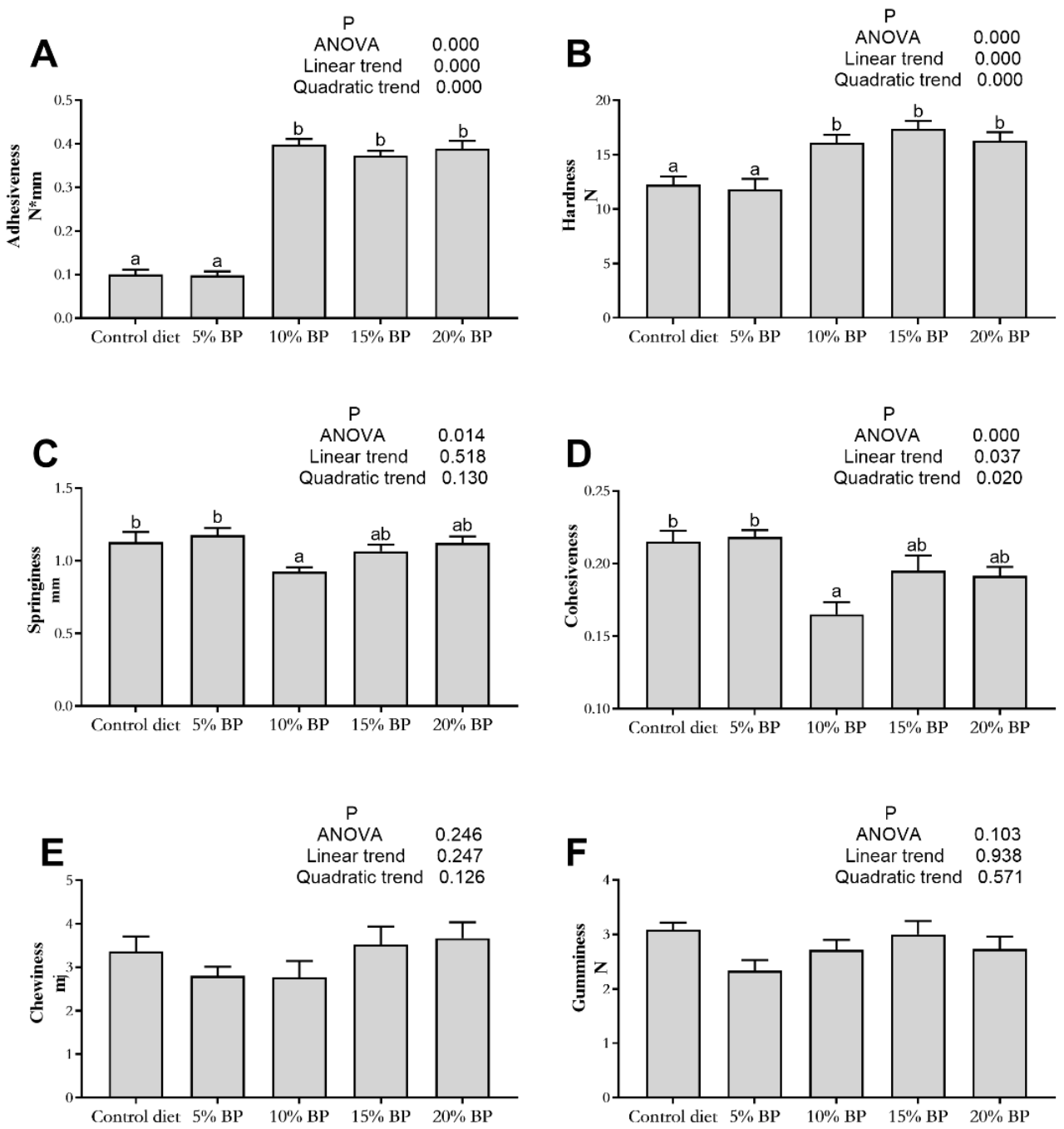

Figure 1. Effects of paper mulberry (BP) on muscle texture parameters of grass carp. (A) Adhesiveness; (B) hardness; (C) springiness; (D) cohesiveness; (E) chewiness; (F) gumminess. Different letters indicate significant differences $(p<0.05, n=3)$.

Table 5. Water-holding capacity and $\mathrm{pH}$ of muscle in grass carp fed a diet with paper mulberry (BP) for 8 weeks.

\begin{tabular}{cccc}
\hline & Water Loss (\%) & Lipid Loss (\%) & pH \\
\hline Control diet & $5.28 \pm 0.89^{\mathrm{a}}$ & $2.64 \pm 0.20$ & $6.63 \pm 0.05$ \\
$5 \% \mathrm{BP}$ & $9.38 \pm 0.44^{\mathrm{b}}$ & $2.97 \pm 0.21$ & $6.81 \pm 0.06$ \\
$10 \% \mathrm{BP}$ & $10.56 \pm 0.74^{\mathrm{b}}$ & $2.71 \pm 0.35$ & $6.67 \pm 0.04$ \\
$15 \% \mathrm{BP}$ & $9.25 \pm 1.02^{\mathrm{b}}$ & $2.05 \pm 0.30$ & $6.73 \pm 0.05$ \\
$20 \% \mathrm{BP}$ & $8.77 \pm 0.48^{\mathrm{b}}$ & $2.66 \pm 0.10$ & $6.69 \pm 0.01$ \\
P value & & & \\
ANOVA & 0.000 & 0.139 & 0.113 \\
Linear trend & 0.028 & 0.293 & 0.858 \\
Quadratic trend & 0.000 & 0.568 & 0.524
\end{tabular}

Data are expressed as mean \pm S. E. Values with different superscripts $\left({ }^{a}, b, c\right)$ are significantly different $(p<0.05$, $n=3)$. 
Table 6. The content of TVB-N and TBARs of muscle in grass carp fed a diet with paper mulberry (BP) for 8 weeks.

\begin{tabular}{ccc}
\hline & TVB-N (mg/100g) & TBARs (mg MDA/kg) \\
\hline Control diet & $10.13 \pm 0.10$ & $0.45 \pm 0.02^{\mathrm{b}}$ \\
$5 \% \mathrm{BP}$ & $10.42 \pm 0.50$ & $0.32 \pm 0.02^{\mathrm{ab}}$ \\
$10 \% \mathrm{BP}$ & $10.28 \pm 0.09$ & $0.40 \pm 0.01^{\mathrm{ab}}$ \\
$15 \% \mathrm{BP}$ & $10.66 \pm 0.13$ & $0.42 \pm 0.08^{\mathrm{ab}}$ \\
$20 \% \mathrm{BP}$ & $11.08 \pm 0.05$ & $0.25 \pm 0.00^{\mathrm{a}}$ \\
$p$ value & & \\
ANOVA & 0.118 & 0.028 \\
Linear trend & 0.010 & 0.082 \\
Quadratic trend & 0.029 & 0.193
\end{tabular}

TVB- $N=$ total volatile base nitrogen, TBARs = thiobarbituric reactive substances, MDA = malonaldehyde. Data are expressed as mean \pm S.E. Values with different superscripts $\left({ }^{a}{ }^{a}\right)$ are significantly different $(p<0.05, n=3)$.

\subsection{Effect of Paper Mulberry on Partial Muscle Enzymes Activity of Grass Carp}

As is described in Table 7, there are no significant differences in muscle lactate, HYP and TnT contents of grass carp muscle among all groups $(p>0.05)$. Positive linear and quadratic trends were found between paper mulberry levels and glycogen in grass carp muscle $(p<0.05)$, and the muscle glycogen of grass carp in the 20\%BP group was significantly lower than that of the control diet $(p<0.05)$.

Table 7. Muscle enzyme activity in grass carp fed a diet with paper mulberry (BP) for 8 weeks.

\begin{tabular}{ccccc}
\hline & $\begin{array}{c}\text { Lactate } \\
\text { (mmol/gprot) }\end{array}$ & $\begin{array}{c}\text { Hydroxyproline } \\
\text { (ug/100mg) }\end{array}$ & $\begin{array}{c}\text { Troponin T } \\
\text { (ng/dL) }\end{array}$ & $\begin{array}{c}\text { Glycogen } \\
\text { (mg/g) }\end{array}$ \\
\hline Control diet & $2.59 \pm 0.25$ & $3.77 \pm 0.25$ & $387.22 \pm 36.45$ & $1.24 \pm 0.05^{\mathrm{b}}$ \\
$5 \% \mathrm{BP}$ & $2.33 \pm 0.30$ & $3.03 \pm 0.19$ & $428.94 \pm 46.69$ & $1.19 \pm 0.03^{\mathrm{ab}}$ \\
$10 \% \mathrm{BP}$ & $2.48 \pm 0.29$ & $3.46 \pm 0.56$ & $421.38 \pm 28.75$ & $1.26 \pm 0.05^{\mathrm{b}}$ \\
$15 \% \mathrm{BP}$ & $2.45 \pm 0.15$ & $3.41 \pm 0.48$ & $384.09 \pm 45.39$ & $1.15 \pm 0.01^{\mathrm{ab}}$ \\
$20 \% \mathrm{BP}$ & $2.36 \pm 0.41$ & $3.44 \pm 0.55$ & $472.58 \pm 39.15$ & $1.06 \pm 0.02^{\mathrm{a}}$ \\
$p$ value & & & & \\
ANOVA & 0.973 & 0.831 & 0.527 & 0.012 \\
Linear trend & 0.706 & 0.845 & 0.320 & 0.007 \\
Quadratic trend & 0.921 & 0.789 & 0.564 & 0.006 \\
\hline
\end{tabular}

Data are expressed as mean \pm S. E. Values with different superscripts $\left({ }^{a, b}\right)$ are significantly different $(p<0.05$, $n=3)$.

\subsection{Effect of Paper Mulberry on Muscle Morphology of Grass Carp}

The results of HE staining are shown in Figure 2, and the effects of BP on muscle fiber diameter and density are listed in Table 8 . The levels of paper mulberry linearly and quadratically affected the muscle fiber diameter and density of grass carp $(p<0.05)$. In comparison to the control diet, the muscle fiber diameter of grass carp decreased significantly in the $15 \% \mathrm{BP}$ and $20 \% \mathrm{BP}$ groups $(p>0.05)$. Moreover, the muscle fiber density of grass carp increased significantly when the addition of paper mulberry in the diet reached $10 \%(p<0.05)$. 


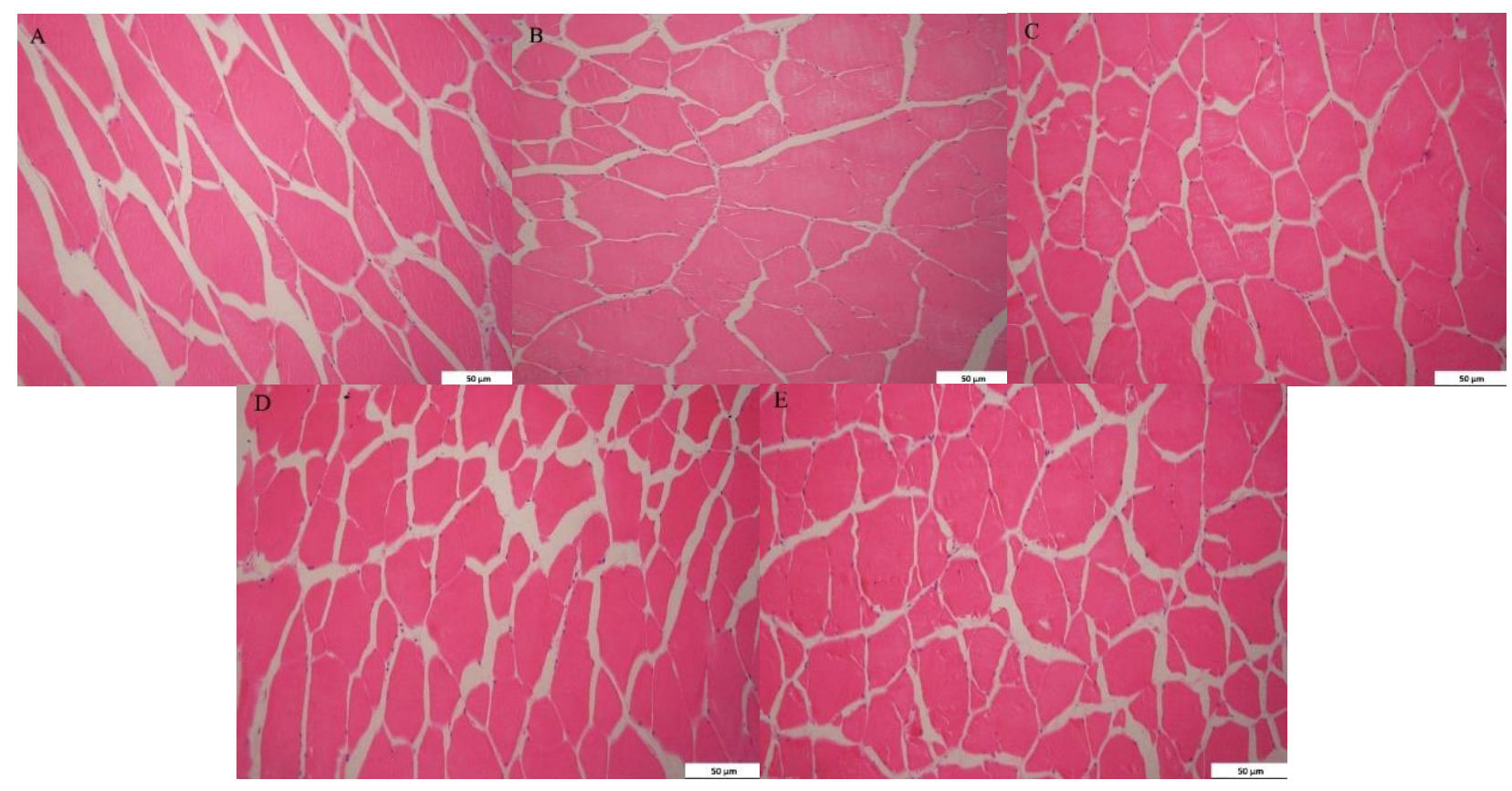

Figure 2. The morphology of the muscle of grass carp fed a diet with paper mulberry (BP) for 8 weeks. (A) Control diet $200 \times$; (B) 5\%BP group 200×; (C) 10\%BP group 200×; (D) 15\%BP group 200×; (E) 20\%BP group 200×.

Table 8. Muscle fiber diameter and density in grass carp fed a diet with paper mulberry (BP) for 8 weeks.

\begin{tabular}{ccc}
\hline & Fiber Diameter $(\mu \mathrm{m})$ & ${\text { Fiber Density }\left(\mathbf{N} / \mathbf{m m}^{\mathbf{2}}\right)}$ \\
\hline Control diet & $62.31 \pm 2.12^{\mathrm{b}}$ & $108.30 \pm 5.07^{\mathrm{a}}$ \\
$5 \% \mathrm{BP}$ & $62.50 \pm 1.30^{\mathrm{b}}$ & $126.91 \pm 7.66^{\mathrm{ab}}$ \\
$10 \% \mathrm{BP}$ & $56.41 \pm 1.76^{\mathrm{ab}}$ & $139.67 \pm 5.21^{\mathrm{b}}$ \\
$15 \% \mathrm{BP}$ & $51.71 \pm 0.66^{\mathrm{a}}$ & $170.70 \pm 5.73^{\mathrm{c}}$ \\
$20 \% \mathrm{BP}$ & $51.26 \pm 1.28^{\mathrm{a}}$ & $185.05 \pm 9.26^{\mathrm{c}}$ \\
$p$ value & & \\
ANOVA & 0.000 & 0.000 \\
Linear trend & 0.000 & 0.000 \\
Quadratic trend & 0.000 & 0.000 \\
\hline
\end{tabular}

Data are expressed as mean \pm S.E. Values with different superscripts $\left({ }^{a, b}, \mathrm{c}\right)$ are significantly different $(p<0.05$ $n=3)$.

\subsection{Effect of Paper Mulberry on Muscle Growth-Related Gene Expression of Grass Carp}

As shown in Figures 3 and 4, adding paper mulberry had no significant influence on myogenic factor 5 (Myf5) and myogenic regulatory factor 4 (Mrf4) expressions in the muscle of grass carp $(p>0.05)$. Increasing the dietary paper mulberry contents linearly and quadratically increased the expressions of MyoD, myogenin (MyoG), Pax7, MSTN1 and IGF2 $(p<0.05)$. In comparison to the control diet, the expressions of MyoD, MyoG, Pax7 and MSTN1 improved significantly after adding 10\% paper mulberry to the diet $(p<0.05)$, and the expression of IGF2 was significantly increased in the 20\%BP group $(p<0.05)$. 

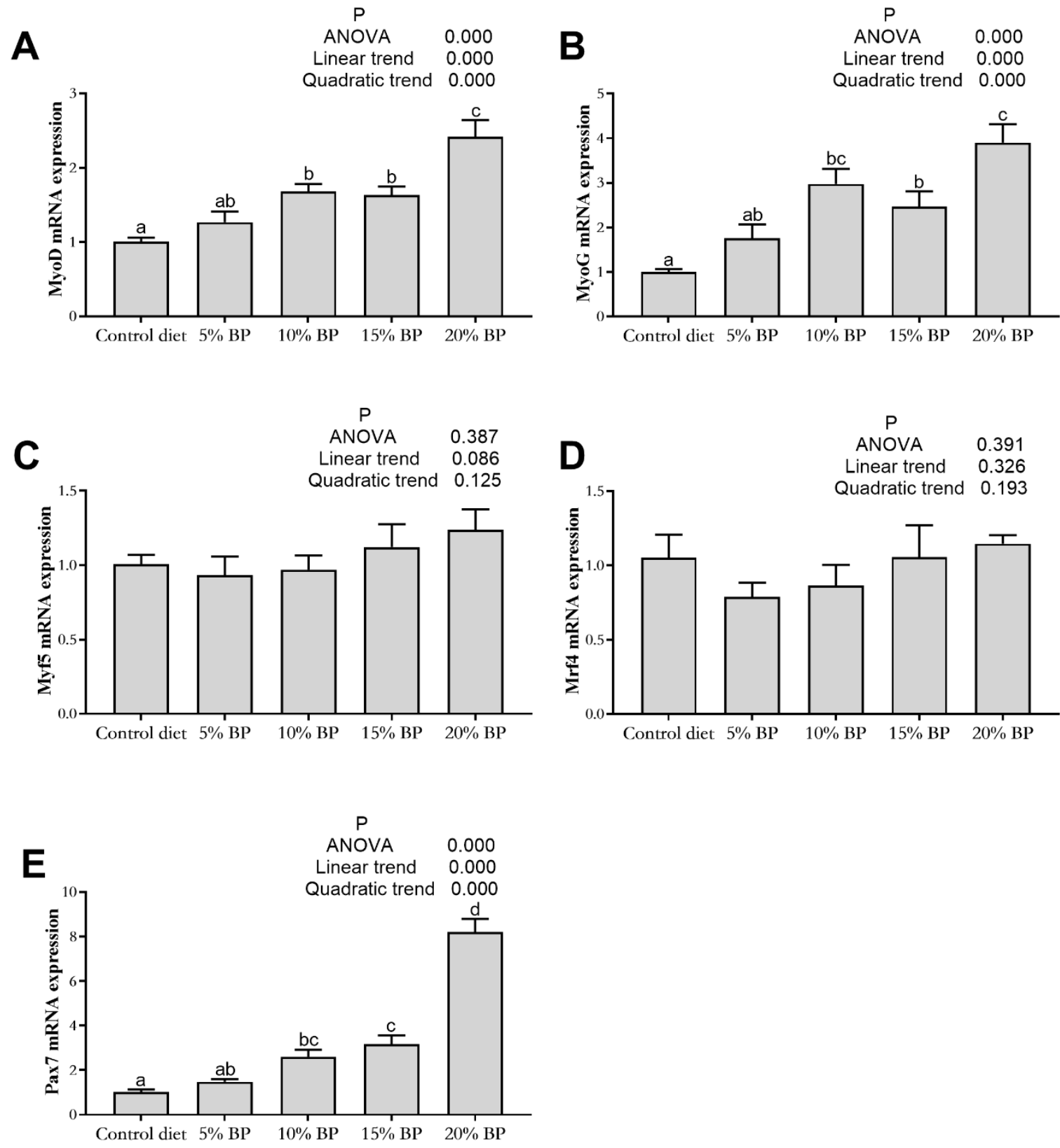

Figure 3. The gene expression of myogenic regulatory factors in the muscle of grass carp fed a diet with paper mulberry (BP) for 8 weeks. MyoD = myoblast determination protein (A), MyoG = myogenin (B), Myf5 = myogenic factor 5 (C), Mrf4 = myogenic regulatory factor 4 (D), Pax7 = paired box protein 7 (E). Different letters indicate significant $\left({ }^{a}, b, c, d\right)$ differences $(p<0.05, n=3)$. 

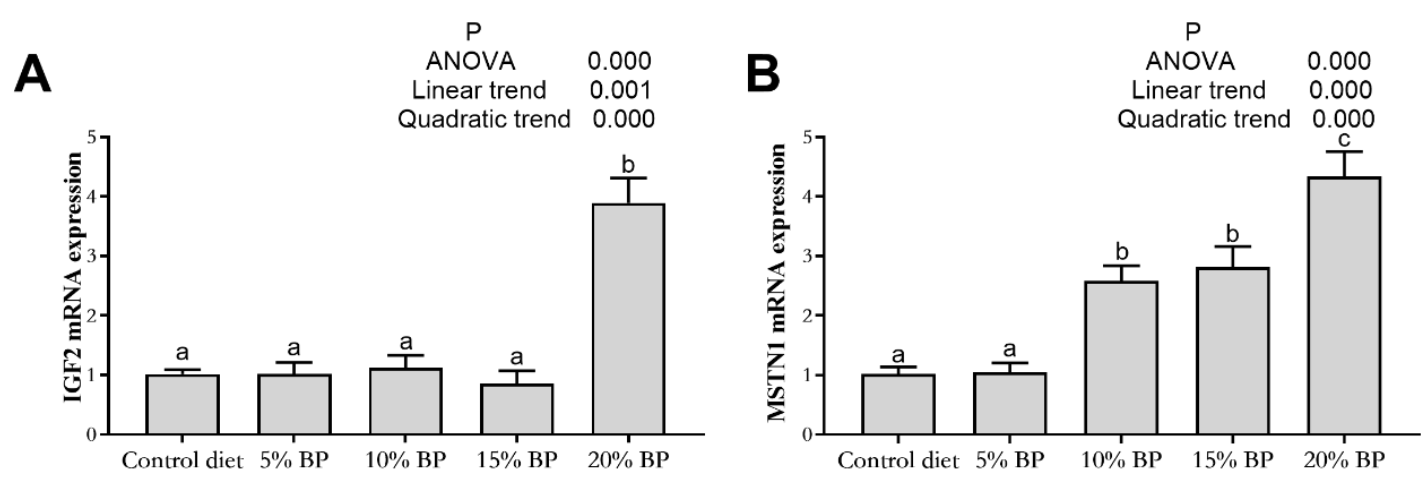

Figure 4. The gene expression of muscle growth regulatory factors in the muscle of grass carp fed a diet with paper mulberry (BP) for 8 weeks. IGF2 = insulin-like growth factor 2 (A), MSTN1 = myostatin 1 (B). Different letters (a,b)indicate significant differences $(p<0.05, n=3)$.

\section{Discussion}

The content of the crude protein of paper mulberry varies from $18 \%$ to $22 \%$, which is higher than other xylophyta, such as Morus alba L. [35]. A previous study found that the lignin content and composition, especially the level of syringyl-lignin, affected the digestibility of forage [36]. Peng et al. [37] found that the caffeic acid 3-O-methyltransferase gene family that affected syringyl-lignin biosynthesis expended in paper mulberry through the genome analysis. Paper mulberry has been used to feed livestock for thousands of years, but few researchers have studied its effects on aquatic animals. Previous research found that adding $25 \%$ and $50 \%$ paper mulberry improved the growth performance of goat [11]. However, adding paper mulberry reduced the apparent digestibility of crude protein and dry matter in pigs, and the appropriate addition of paper mulberry in pigs was no more than $10 \%$ [8]. In the present study, adding $10 \%$ paper mulberry decreased the SGR of grass carp. These discrepancies may be due to the high fiber content of paper mulberry. In general, ruminant could digest the crude fiber effectively, but the high content of fiber affected the growth performance of monogastric animals. Compared with livestock, the digestive system of aquatic animals is more primitive. Research about fish found that high levels of fiber in the diet restricted the digestive enzymes function and affected the digestibility of Atlantic cod (Gadus morhua L.) [38] and rainbow trout (Oncorhynchus mykiss) [39]. Moreover, a previous study found that grass carps lack genes related to cellulase synthesis, even as an herbivorous fish [40]. Studies found that tannin decreased the feed intake of common carp [41], inhibited the activity of $\alpha$-amylase and lipase and had toxicity on tilapia (Oreochromis mossambicus) [42].

The TBARs are wildly used as a biomarker of secondary lipid oxidation. Lipid oxidation damaged the meat quality through producing undesirable rancid off-flavors or even toxins [43]. In the present study, adding $20 \%$ paper mulberry significantly decreased the TBARs in the muscle of grass carp. It indicated that the diet with paper mulberry supplementation might be helpful to extend the storage time by preventing the lipid oxidation. This effect was due to the antioxidant function of paper mulberry. Preliminary studies proved that the polysaccharides extracted from paper mulberry had strong antioxidant activities [44,45], and a diet supplemented with $10 \%$ paper mulberry could improve the antioxidant capacity of cows [46]. However, in comparison to the cows, the TBARs in the muscle of grass carp decreased significantly only when the addition of paper mulberry reached $20 \%$ in our experiment. This may be because the primitive digestive system of grass carp limited the absorption of polysaccharides from paper mulberry.

Muscle $\mathrm{pH}$ and WHC are important parameters in evaluating muscle quality. After death, the muscle glycogen is degraded by glycolytic enzymes. It leads to muscle acidification and decreases the $\mathrm{pH}$ of the muscle [47]. In the present study, the content of muscle glycogen in the $20 \% \mathrm{BP}$ group decreased significantly, but the content of lactate in the muscle was no different among all groups. Paper mulberry had no significant influence 
on muscle $\mathrm{pH}$ among all groups. This corresponded to the study of sheep [48] and pig [49]. The ability of meat to retain both inherent water and added water is defined as WHC [50], which has a great impact on the meat texture because the large reduction of water in meat leads to an increase in hardness [51]. The present study showed that adding paper mulberry increased the drip loss significantly. A similar result was found in the research of Song et al. [52], which found that adding paper mulberry decreased the WHC of pig muscle and the meat quality. Interestingly, Song et al. [52] found that in the same low-protein diet, the addition of fermented paper mulberry had no significant effect on the WHC of pig muscle. The influence of paper mulberry on the WHC of muscle might be related to the content of anti-nutrition factors in paper mulberry, because some studies proved that it was reduced after fermentation, especially tannin [16,53]. Besides WHC, the muscle fat content also affects the hardness of meat. Previous studies proved that the high content of fat affected the structure of muscle and decreased the firmness of meat $[54,55]$. In the present study, the muscle fat content decreased with the improvement of the addition of paper mulberry, and adding $10 \%$ and $15 \%$ paper mulberry had significant influence on it. This result showed that paper mulberry might affect the muscle texture of grass carp.

In order to further study the effects of paper mulberry on muscle quality of grass carp, muscle texture was detected by TPA. In this experiment, when the supplementation of paper mulberry reached 10\%, the muscle hardness and adhesiveness of grass carp increased significantly. As mentioned above, the increase in hardness corresponded to the decline of muscle WHC and fat content in grass carp. Texture is one of the most important quality indicators of fish. Among textural parameters, muscle hardness is a vital factor affecting acceptability of fillets [56,57]. Previous studies found the feeding ingredients affected the textural qualities of grass carp. After feeding broad bean (Vicia faba), the muscle hardness of grass carp increased and the fillets of grass carp were more compact and crisper than ordinary grass carp $[58,59]$. In addition, soybean meal also increased the hardness of grass carp muscle [60]. However, Azm et al. [61] found that replacing the rapeseed meal with distiller's dried grains with solubles negatively affected the hardness of grass carp muscle. In this experiment, the result that muscle hardness increased after adding 10\% paper mulberry in the diet indicated that paper mulberry was helpful in improving the fillet quality of grass carp.

In this experiment, when the supplementation of paper mulberry reached $10 \%$, the muscle fiber diameter of grass carp decreased while the muscle fiber density increased. Muscle hardness has been reported to be associated with the muscle fiber diameter and density. In general, the lower muscle fiber diameter resulted in the higher density of muscle fiber and higher muscle hardness [62]. Lin et al. [55] explained that this was because high fiber density represented a higher surface-to-volume ratio of muscle fibers and led to the higher amount of the connective tissue surrounding each fiber.

MyoD, MyoG, Myf5 and Mrf4 are the four members of MRFs. MyoD is critical in skeletal myogenesis due to its ability to initiate the myogenic program, and Myf5 exhibits redundant functions with myoD [63]. Moreover, both of these two factors were related to the proliferation of myoblasts [64]. MyoG and Mrf4 play essential roles during muscle differentiation $[65,66]$. Pax7 was proved to participate in the induction of the myogenic program during development through regulating MyoD or Myf5 expression [67]. In the present study, the expression of Pax7, MyoD and MyoG increased significantly after adding $15 \%$ paper mulberry. This indicated that paper mulberry would affect the muscle fiber development of grass carp. Similar results were reported in grass carp [68], Senegalese sole (Solea senegalensis) [69] and Zebrafish (D. rerio) [70] when fed with plant proteins. IGFs and MSTN are the positive and negative transcription factors of MRFs [71]. Previous research proved the negative influence of MSTNs on the muscle growth of grass carp [72], blunt snout bream (Megalobrama amblycephala) [71] and bighead carp (Aristichthys nobilis) [73]. In this experiment, the MSTN expression increased significantly after adding $10 \%$ paper mulberry. It was perhaps the cause of the decrease in growth performance. 


\section{Conclusions}

With the increase in dietary paper mulberry content, the growth performance of grass carp decreased while the muscle quality of grass carp improved. When the supplementation of paper mulberry reached $10 \%$, it had a negative effect on the growth performance of grass carp. However, it improved the grass carp muscle texture through improving muscle hardness and adhesiveness. Moreover, it reduced muscle fat accumulation and the muscle fiber diameter of grass carp.

Author Contributions: Conceptualization, Z.W.; methodology, Z.W.; software, J.B. and Z.A.; validation, T.T.; formal analysis, T.T. and Z.A.; investigation, Z.A. and T.T.; resources, S.L.; data curation, Z.W.; writing—original draft preparation, T.T.; writing—review and editing, Z.W.; visualization, Z.W.; supervision, Z.W and Y.H.; project administration, S.L.; funding acquisition, S.L. All authors have read and agreed to the published version of the manuscript.

Funding: This research was supported by High-Level Talent Agglomeration Program of Hunan, China (Grant No. 2019RS1044), Natural Science Foundation of Hunan Province of China (Grant No. 2020JJ5356), Education Bureau of Hunan Province of China (Grant No. 18B003), State Key Laboratory of Developmental Biology of Freshwater Fish (Grant No. 2019KF003).

Institutional Review Board Statement: This study was conducted according to the guidelines of the Basel Declaration and recommendations of the Guide for the Care and Use of Laboratory Animals, the ethics committee of Hunan Normal University. The protocol was approved by the ethics committee of Hunan Normal University under permit No. 20200012.

Data Availability Statement: The data presented in this study are available on request from the corresponding author.

Conflicts of Interest: The authors declare no conflict of interest.

\section{References}

1. Penailillo, J.; Olivares, G.; Moncada, X.; Payacan, C.; Chang, C.S.; Chung, K.F.; Matthews, P.J; Seelenfreund, A.; Seelenfreund, D. Sex distribution of paper mulberry (Broussonetia Papyrifera) in the pacific. PLoS ONE 2016, 11, e0161148. [CrossRef] [PubMed]

2. Ko, H.-J.; Jin, J.-H.; Kwon, O.-S.; Kim, J.-T.; Son, K.-H.; Kim, H.-P. Inhibition of Experimental Lung Inflammation and Bronchitis by Phytoformula Containing Broussonetia papyrifera and Lonicera japonica. Biomol. Ther. 2011, 19, 324-330. [CrossRef]

3. Wu, X.Z.; Yang, P.L.; Gao, X.H.; Wen, Z.G.; Dai, S.F.; Zhu, M.X.; Wang, L.X. Effects of replacement of alfalfa by big-leaf mulberry on growth performance, digestion and meat quality in growing rabbits. World Rabbit. Sci. 2019, 27, 199-205. [CrossRef]

4. Kandylis, K.; Hadjigeorgiou, I.; Harizanis, P. The nutritive value of mulberry leaves (Morus alba) as a feed supplement for sheep. Trop. Anim. Health Prod. 2009, 41, 17-24. [CrossRef] [PubMed]

5. Tao, H.; Si, B.; Xu, W.; Tu, Y.; Diao, Q. Effect of Broussonetia papyrifera L. silage on blood biochemical parameters, growth performance, meat amino acids and fatty acids compositions in beef cattle. Asian-Australas. J. Anim. Sci. 2020, 33, 732-741. [CrossRef]

6. Lacassagne, L.; Francesch, M.; Carré, B.; Melcion, J. Utilization of tannin-containing and tannin-free faba beans (Vicia faba) by young chicks: Effects of pelleting feeds on energy, protein and starch digestibility. Anim. Feed. Sci. Technol. 1988, 20, 59-68. [CrossRef]

7. Frazier, R.A.; Deaville, E.R.; Green, R.J.; Stringano, E.; Willoughby, I.; Plant, J.; Mueller-Harvey, I. Interactions of tea tannins and condensed tannins with proteins. J. Pharm. Biomed. Anal. 2010, 51, 490-495. [CrossRef]

8. Yang, Q.C.; Chen, S.H.; Liu, Y. The effect of Broussonetia papyrifera leaf on the production performance, meat quality and apparent digestibility of fatting pigs. J. Henan Agric. Sci. 2014, 43, 133-137.

9. Martinez, M.; Motta, W.; Cervera, C.; Pla, M. Feeding mulberry leaves to fattening rabbits: Effects on growth, carcass characteristics and meat quality. Anim. Sci. 2005, 80, 275-280. [CrossRef]

10. Leterme, P.; Botero, M.; Londoño, A.M.; Bindelle, J.; Buldgen, A. Nutritive value of tropical tree leaf meals in adult sows. Anim. Sci. 2006, 82, 175-182. [CrossRef]

11. Hua, J.; Xu, T.; Shen, Q.; Liu, Y.; Huang, G.; Rao, D.; Song, C.; Wang, J. Productive and metabolic increments of the inclusion of Broussonetia papyrifera to replace maize silage in growing goats. Czech J. Anim. Sci. 2020, 65, 303-310. [CrossRef]

12. Su, Y.; Chen, G.; Cai, Y.; Gao, B.; Zhi, X.; Chang, F. Effects of Broussonetia papyrifera-fermented feed on the growth performance and muscle quality of Hu sheep. Can. J. Anim. Sci. 2020, 100, 771-780. [CrossRef]

13. Andrés-Bello, A.; Barreto-Palacios, V.; Garciasegovia, P.; Mirbel, J.; Martínez-Monzó, J. Effect of pH on Color and Texture of Food Products. Food Eng. Rev. 2013, 5, 158-170. [CrossRef]

14. Koohmaraie, M.; Shackelford, S.D.; Wheeler, T.L.; Lonergan, S.M.; Doumit, M.E. A muscle hypertrophy condition in lamb (callipyge): Characterization of effects on muscle growth and meat quality traits. J. Anim. Sci. 1995, 73, 3596-3607. [CrossRef] [PubMed] 
15. Offer, G.; Cousins, T. The mechanism of drip production: Formation of two compartments of extracellular space in muscle post mortem. J. Sci. Food Agric. 1992, 58, 107-116. [CrossRef]

16. Xiong, L.Y.; Cai, R.X.; Liu, Y.F. Effects of fermented Broussonetia papyrifera leaf on slaughter performances and meat quality of AA broiler. Guangdong Agric. Sci. 2016, 43, 157-161.

17. Hocquette, J.F.; Gondret, F.; Baéza, E.; Médale, F.; Jurie, C.; Pethick, D.W. Intramuscular fat content in meat-producing animals: Development, genetic and nutritional control, and identification of putative markers. Animal 2010, 4, 303-319. [CrossRef] [PubMed]

18. Chen, J.J.; Zhang, H.J.; Liu, N.N. Effects of wormwood leaf complex on growth and immune performance of carp before and after fermentation. J. Gansu Agric. Univ. 2020, 55, 7-13.

19. Weatherley, A.H.; Gill, H.S.; Lobo, A.F. Recruitment and maximal diameter of axial muscle fibres in teleosts and their relationship to somatic growth and ultimate size. J. Fish Biol. 1988, 33, 851-859. [CrossRef]

20. Wu, T.; Zhang, Z.; Yuan, Z.; Lo, L.J.; Chen, J.; Wang, Y.; Peng, J. Distinctive Genes Determine Different Intramuscular Fat and Muscle Fiber Ratios of the longissimus dorsi Muscles in Jinhua and Landrace Pigs. PLoS ONE 2013, 8, e53181. [CrossRef]

21. Asaduzzaman, M.; Ikeda, D.; Abol-Munafi, A.B.; Bulbul, M.; Ali, E.; Kinoshita, S.; Watabe, S.; Kader, A. Dietary supplementation of inosine monophosphate promotes cellular growth of muscle and upregulates growth-related gene expression in Nile tilapia Oreochromis niloticus. Aquaculture 2017, 468, 297-306. [CrossRef]

22. Valente, L.M.; Moutou, K.A.; Conceição, L.E.; Engrola, S.; Fernandes, J.M.; Johnston, I.A. What determines growth potential and juvenile quality of farmed fish species? Rev. Aquac. 2013, 5, S168-S193. [CrossRef]

23. Akolkar, D.B.; Asaduzzaman, M.; Kinoshita, S.; Asakawa, S.; Watabe, S. Characterization of Pax3 and Pax7 genes and their expression patterns during different development and growth stages of Japanese pufferfish Takifugu rubripes. Gene 2016, 575, 21-28. [CrossRef] [PubMed]

24. Alami-Durante, H.; Wrutniak-Cabello, C.; Kaushik, S.; Médale, F. Skeletal muscle cellularity and expression of myogenic regulatory factors and myosin heavy chains in rainbow trout (Oncorhynchus mykiss): Effects of changes in dietary plant protein sources and amino acid profiles. Comp. Biochem. Physiol. Part A Mol. Integr. Physiol. 2010, 156, 561-568. [CrossRef]

25. Li, X.; Chen, S.; Sun, J.; Huang, X.; Tang, H.; He, Y.; Pan, Q.; Gan, L. Partial substitution of soybean meal with faba bean meal in grass carp (Ctenopharyngodon idella) diets, and the effects on muscle fatty acid composition, flesh quality, and expression of myogenic regulatory factors. J. World Aquac. Soc. 2019, 51, 1145-1160. [CrossRef]

26. FAO Agriculture, Capture and Globle Production Database 2020. Available online: http://www.fao.org/fishery/statistics/ global-aquaculture-production/query/en (accessed on 24 May 2021).

27. Li, X.; Bickerdike, R.; Lindsay, E.; Campbell, P.; Nickell, D.; Dingwall, A.A.; Johnston, I.A. Hydroxylysyl Pyridinoline Cross-Link Concentration Affects the Textural Properties of Fresh and Smoked Atlantic Salmon (Salmo salarL.) Flesh. J. Agric. Food Chem. 2005, 53, 6844-6850. [CrossRef]

28. Essid, I.; Tajine, S.; Gharbi, S.; Bellagha, S. Use of pomegranate peel and artichoke leaf extracts to improve the quality of marinated sardine (Sardinella aurita) fillets. J. Food Sci. Technol. 2020, 57, 713-722. [CrossRef]

29. Wang, Z.; He, Z.; Gan, X.; Li, H. Interrelationship among ferrous myoglobin, lipid and protein oxidations in rabbit meat during refrigerated and superchilled storage. Meat Sci. 2018, 146, 131-139. [CrossRef]

30. Zhang, X.; Wang, J.; Tang, R.; He, X.; Li, L.; Takagi, Y.; Li, D. Improvement of Muscle Quality of Grass Carp (Ctenopharyngodon idellus) With a Bio-Floating Bed in Culture Ponds. Front. Physiol. 2019, 10, 683. [CrossRef] [PubMed]

31. Lee, S.-J.; McPherron, A.C. Regulation of myostatin activity and muscle growth. Proc. Natl. Acad. Sci. USA 2001, 98, 9306-9311. [CrossRef]

32. Bustin, S.A.; Benes, V.; Garson, J.A.; Hellemans, J.; Huggett, J.; Kubista, M.; Mueller, R.; Nolan, T.; Pfaffl, M.W.; Shipley, G.L.; et al. The MIQE Guidelines: Minimum Information for Publication of Quantitative Real-Time PCR Experiments. Clin. Chem. 2009, 55, 611-622. [CrossRef]

33. Livak, K.J.; Schmittgen, T.D. Analysis of relative gene expression data using real-time quantitative PCR and the 2(-Delta Delta C(T)) Method. Methods 2001, 25, 402-408. [CrossRef] [PubMed]

34. Wei, Y.; Shen, H.; Xu, W.; Pan, Y.; Chen, J.; Zhang, W.; Mai, K. Replacement of dietary fishmeal by Antarctic krill meal on growth performance, intestinal morphology, body composition and organoleptic quality of large yellow croaker Larimichthys crocea. Aquaculture 2019, 512, 734281. [CrossRef]

35. Pi, Z.; Shen, S.H. Research on paper mulberry as a new type of protein feedstuff. Feed Ind. 2018, 39, 23-28.

36. Wu, Z.Y.; Wang, N.F.; Hisano, H.; Cao, Y.P.; Wu, F.Y.; Liu, W.W.; Bao, Y.; Wang, Z.Y.; Fu, C.X. Simultaneous regulation of F5H in COMT-RNAi transgenic switchgrass alters effects of COMT suppression on syringyl lignin biosynthesis. Plant Biotechnol. J. 2019, 17, 836-845. [CrossRef]

37. Peng, X.; Liu, H.; Chen, P.; Tang, F.; Hu, Y.; Wang, F.; Pi, Z.; Zhao, M.; Chen, N.; Chen, H.; et al. A Chromosome-Scale Genome Assembly of Paper Mulberry (Broussonetia papyrifera) Provides New Insights into Its Forage and Papermaking Usage. Mol. Plant 2019, 12, 661-677. [CrossRef]

38. Lekva, A.; Hansen, A.-C.; Rosenlund, G.; Karlsen, Ø.; Hemre, G.-I. Energy dilution with $\alpha$-cellulose in diets for Atlantic cod (Gadus morhua L.) juveniles-Effects on growth, feed intake, liver size and digestibility of nutrients. Aquaculture 2010, 300, 169-175. [CrossRef]

39. Glencross, B. The influence of soluble and insoluble lupin non-starch polysaccharides on the digestibility of diets fed to rainbow trout (Oncorhynchus mykiss). Aquaculture 2009, 294, 256-261. [CrossRef] 
40. Wang, Y.; Lu, Y.; Zhang, Y.; Ning, Z.; Li, Y.; Zhao, Q.; Lu, H.; Huang, R.; Xia, X.; Feng, Q.; et al. The draft genome of the grass carp (Ctenopharyngodon idellus) provides insights into its evolution and vegetarian adaptation. Nat. Genet. 2015, 47, 625-631. [CrossRef] [PubMed]

41. Becker, K.; Makkar, H. Effects of dietary tannic acid and quebracho tannin on growth performance and metabolic rates of common carp (Cyprinus carpio L.). Aquaculture 1999, 175, 327-335. [CrossRef]

42. Saha, N.; Kaviraj, A. Acute and chronic toxicity of tannic acid and spent bark of cinchona to tilapia Oreochromis mossambicus. Aquaculture 1996, 145, 119-127. [CrossRef]

43. Eymard, S.; Carcouet, E.; Rochet, M.-J.; Dumay, J.; Chopin, C.; Genot, C. Development of lipid oxidation during manufacturing of horse mackerel surimi. J. Sci. Food Agric. 2005, 85, 1750-1756. [CrossRef]

44. Han, Q.; Wu, Z.; Huang, B.; Sun, L.; Ding, C.; Yuan, S.; Zhang, Z.; Chen, Y.; Hu, C.; Zhou, L.; et al. Extraction, antioxidant and antibacterial activities of Broussonetia papyrifera fruits polysaccharides. Int. J. Biol. Macromol. 2016, 92, 116-124. [CrossRef] [PubMed]

45. Sun, J.; Liu, S.-F.; Zhang, C.-S.; Yu, L.-N.; Bi, J.; Zhu, F.; Yang, Q.-L. Chemical Composition and Antioxidant Activities of Broussonetia papyrifera Fruits. PLoS ONE 2012, 7, e32021. [CrossRef]

46. Si, B.; Tao, H.; Zhang, X.; Guo, J.; Cui, K.; Tu, Y.; Diao, Q.-Y. Effect of Broussonetia papyrifera L. (paper mulberry) silage on dry matter intake, milk composition, antioxidant capacity and milk fatty acid profile in dairy cows. Asian-Australas. J. Anim. Sci. 2018, 31, 1259-1266. [CrossRef] [PubMed]

47. Fernandez, X.; Mågård, M.; Tornberg, E. Glycolytic Potential in Porcine Longissimus Muscle before and after Transport: An in Vivo Study. J. Muscle Foods 1992, 3, 83-89. [CrossRef]

48. Hua, J.; Cong, G.; Guo, L.; Chen, C.; Song, C. Effects of Broussonetia papyrifera leaves on rumen fermentation characteristics, digestibility and metabolism, production performance, and meat quality of Huanghuai white goat. J. Nanjing Agric. Univ. 2019, 42, 924-931. [CrossRef]

49. Zhang, X.; Zhu, S.Z.; Yang, Q.; Su, Z.X.; Tan, H.; Liu, C.F.; Wu, M.S.; Duan, Y.h.; Yin, Y.L. Effects of Broussonetia papyrifera fermented feed on growth performance, carcass quality and meat quality of xiangsha pigs commercial line of commercial pigs. Chin. J. Anim. Nutr. 2019, 12, 5760-5771.

50. Pearce, K.L.; Rosenvold, K.; Andersen, H.J.; Hopkins, D.L. Water distribution and mobility in meat during the conversion of muscle to meat and ageing and the impacts on fresh meat quality attributes-A review. Meat Sci. 2011, 89, 111-124. [CrossRef]

51. Hughes, J.; Oiseth, S.; Purslow, P.; Warner, R. A structural approach to understanding the interactions between colour, waterholding capacity and tenderness. Meat Sci. 2014, 98, 520-532. [CrossRef]

52. Song, B.; Zheng, C.B.; Zhong, Y.Z.; Tian, M.L.; Wu, M.S.; Yang, Q.; Zhu, S.Z.; Zhang, X.; Li, F.N.; Duan, Y.H.; et al. Effects of low-protein diet supplemented with fermented Broussonetia papyrifera on growth performance, carcass traits and meat quality of finishing pigs. Chin. J. Anim. Nutr. 2020, 32, 4841-4851.

53. Zhang, Y.M.; Yu, H.S.; Zhang, Y.Z.; Wang, D.S. The change of nutrient composition in the broussonetia papyrifera feed fermentation leaves. Feed Ind. 2008, 29, 54-55.

54. Green-Petersen, D.M.B.; Hyldig, G. Variation in Sensory Profile of Individual Rainbow Trout (Oncorhynchus mykiss) from the Same Production Batch. J. Food Sci. 2010, 75, S499-S505. [CrossRef]

55. Lefevre, F.; Cardinal, M.; Bugeon, J.; Labbe, L.; Medale, F.; Quillet, E. Selection for muscle fat content and triploidy affect flesh quality in pan-size rainbow trout, Oncorhynchus mykiss. Aquaculture 2015, 448, 569-577. [CrossRef]

56. Brinker, A.; Reiter, R. Fish meal replacement by plant protein substitution and guar gum addition in trout feed, Part I: Effects on feed utilization and fish quality. Aquaculture 2011, 310, 350-360. [CrossRef]

57. Larsson, T.; Mørkøre, T.; Kolstad, K.; Østbye, T.-K.K.; Afanasyev, S.; Krasnov, A. Gene Expression Profiling of Soft and Firm Atlantic Salmon Fillet. PLoS ONE 2012, 7, e39219. [CrossRef]

58. Lin, W.-L.; Zeng, Q.-X.; Zhu, Z.-W. Different changes in mastication between crisp grass carp (Ctenopharyngodon idellus C.et V) and grass carp (Ctenopharyngodon idellus) after heating: The relationship between texture and ultrastructure in muscle tissue. Food Res. Int. 2009, 42, 271-278. [CrossRef]

59. Yu, E.; Xie, J.; Wang, G.; Yu, D.; Gong, W.; Li, Z.; Wang, H.; Xia, Y.; Wei, N. Gene Expression Profiling of Grass Carp (Ctenopharyngodon idellus) and Crisp Grass Carp. Int. J. Genom. 2014, 2014, 1-15. [CrossRef]

60. Xie, S.; Liu, H.; Jin, J.; Yang, Y.; Zhu, X.; Han, D.; Hu, H. Effect of Different Protein Source Diets on Growth, Sensory Parameters and Flesh texture of On-Growing Grass Carp (Ctenopharyngodon idellus). Isr. J. Aquac. Bamidgeh 2018, 70, 20936. [CrossRef]

61. Azm, F.R.A.; Kong, F.; Tan, Q.; Zhu, Y.; Yu, H.; Yao, J.; Luo, Z. Effects of replacement of dietary rapeseed meal by distiller's dried grains with solubles (DDGS) on growth performance, muscle texture, health and expression of muscle-related genes in grass carp (Ctenopharyngodon idellus). Aquaculture 2021, 533, 736169.

62. Yu, E.-M.; Zhang, H.-F.; Li, Z.-F.; Wang, G.-J.; Wu, H.-K.; Xie, J.; Yu, D.-G.; Xia, Y.; Zhang, K.; Gong, W.-B. Proteomic signature of muscle fibre hyperplasia in response to faba bean intake in grass carp. Sci. Rep. 2017, 7, srep45950. [CrossRef] [PubMed]

63. Rudnicki, M.A.; Schnegelsberg, P.N.; Stead, R.H.; Braun, T.; Arnold, H.-H.; Jaenisch, R. MyoD or Myf-5 is required for the formation of skeletal muscle. Cell 1993, 75, 1351-1359. [CrossRef]

64. Kablar, B.; Krastel, K.; Ying, C.; Tapscott, S.J.; Goldhamer, D.J.; Rudnicki, M.A. Myogenic Determination Occurs Independently in Somites and Limb Buds. Dev. Biol. 1999, 206, 219-231. [CrossRef] 
65. Nabeshima, Y.; Hanaoka, K.; Hayasaka, M.; Esumi, E.; Li, S.; Nonaka, I.; Nabeshima, Y. Myogenin gene disruption results in perinatal lethality because of severe muscle defect. Nature 1993, 364, 532-535. [CrossRef]

66. Braun, T.; Arnold, H. Inactivation of Myf-6 and Myf-5 genes in mice leads to alterations in skeletal muscle development. EMBO J. 1995, 14, 1176-1186. [CrossRef] [PubMed]

67. McKinnell, I.W.; Ishibashi, J.; Le Grand, F.; Punch, V.G.J.; Addicks, G.C.; Greenblatt, J.F.; Dilworth, F.J.; Rudnicki, M.A. Pax7 activates myogenic genes by recruitment of a histone methyltransferase complex. Nat. Cell Biol. 2007, 10, 77-84. [CrossRef]

68. Zhao, H.; Xia, J.; Zhang, X.; He, X.; Li, L.; Tang, R.; Chi, W.; Li, D. Diet Affects Muscle Quality and Growth Traits of Grass Carp (Ctenopharyngodon idellus): A Comparison Between Grass and Artificial Feed. Front. Physiol. 2018, 9, 283. [CrossRef]

69. Valente, L.M.; Cabral, E.M.; Sousa, V.; Cunha, L.M.; Fernandes, J.M. Plant protein blends in diets for Senegalese sole affect skeletal muscle growth, flesh texture and the expression of related genes. Aquaculture 2016, 453, 77-85. [CrossRef]

70. Ulloa, P.E.; Peña, A.A.; Lizama, C.D.; Araneda, C.; Iturra, P.; Neira, R.; Medrano, J.F. Growth Response and Expression of Muscle Growth-Related Candidate Genes in Adult Zebrafish Fed Plant and Fishmeal Protein-Based Diets. Zebrafish 2013, 10, 99-109. [CrossRef]

71. Zeng, C.; Liu, X.-L.; Wang, W.-M.; Tong, J.-G.; Luo, W.; Zhang, J.; Gao, Z.-X. Characterization of GHRs, IGFs and MSTNs, and analysis of their expression relationships in blunt snout bream, Megalobrama amblycephala. Gene 2014, 535, 239-249. [CrossRef] [PubMed]

72. Zheng, G.-D.; Sun, C.-F.; Pu, J.-W.; Chen, J.; Jiang, X.-Y.; Zou, S.-M. Two myostatin genes exhibit divergent and conserved functions in grass carp (Ctenopharyngodon idellus). Gen. Comp. Endocrinol. 2015, 214, 68-76. [CrossRef] [PubMed]

73. Liu, L.; Yu, X.; Tong, J. Molecular characterization of myostatin (MSTN) gene and association analysis with growth traits in the bighead carp (Aristichthys nobilis). Mol. Biol. Rep. 2012, 39, 9211-9221. [CrossRef] [PubMed] 